\title{
Is the pharmaceutical industry's preoccupation with the monotherapy drug model stifling the development of effective new drug therapies?
}

\author{
Ian Edwin Cock $\mathrm{a}^{\mathrm{a}, *}$
}

${ }^{a}$ Environmental Futures Research Institute, Nathan Campus, Griffith University, 170 Kessels Rd, Nathan, Queensland 4111, Australia

bSchool of Environment and Science, Nathan Campus, Griffith University, 170 Kessels Rd, Nathan, Queensland 4111, Australia

*Author of correspondence: Dr. I. E. Cock: E-mail: I.Cock@griffith.edu.au

\begin{abstract}
Drug discovery and development is heavily biased towards the development of monotherapies. Screening, testing and evaluation of mono-entity drugs is generally much simpler than drug combinations, and are generally easier to get approval from the regulatory authorities for their clinical use. However, monotherapy drugs may not have optimal activity, may have associated toxicities, or may lose activity over time as their target develops resistance. Drug combinations, often developed from existing monotherapies, may have improved efficacy and/or be less toxic. Furthermore, existing drugs which have lost efficacy due to the development of resistance can often be re-activated by combining them with other chemical entities. Thus, whilst the current climate for drug approval, registration and clinical use drives the majority of drug development research towards the development of monotherapies, combinations are often a substantial improvement on the original drug. This commentary examines monotherapy and combinational therapy models and discusses the benefits and limitations of each model.
\end{abstract}

Keywords: combinational therapies, synergy, drug repurposing, complementary therapies, natural products, drug repurposing, traditional medicine 


\section{INTRODUCTION}

Whilst the majority of drug discovery is focussed on pure compounds, many chemotherapeutic treatments are instead multifactorial. Combination therapies are the cornerstone of cancer treatment as they are often more effective, reduce drug resistance and may provide multiple therapeutic developments. Similarly, antimicrobial treatment is increasingly reliant on drug combinations. Indeed, monotherapy for malaria, HIV and leprosy is classified as unethical by the WHO (WHO 2018a; WHO 2018b). Whilst many other bacterial treatments are reliant on antibiotic monotherapies, the use of drug combinations is also becoming more common, with drugs such as Augmentin ${ }^{\circledR}$ gaining prominence, particularly for the treatment of resistant bacterial strains. Inflammation is a complex set of symptoms related to other underlying causes (e.g. antigen challenge, tissue damage etc.). The events involved with the initiation and progression of inflammatory diseases are complex and provide numerous targets for medical intervention. Despite this, monotherapies remain the most common treatment modality for inflammation, and combinations are often reserved for the most debilitating cases. This commentary examines the benefits and shortcomings of both the monotherapy and multidrug combination treatment modalities.

\section{THE ONE DRUG, ONE TARGET MODEL OF DRUG THERAPY}

The majority of current drug discovery research is based on the development and identification of single compound drugs. Ideally, these new drugs should be selective and target a single cellular mechanism (i.e. identifying ligands that interact with specific targets). Such a model for drug discovery has been aided by medical science's ever-increasing understanding of the molecular basis of biological processes. Furthermore, the development of high throughput in vitro screening (HTS) assays using validated targets has further aided this approach and has allowed drug researchers to screen vast chemical libraries for biologically active compounds in a relatively short time frame. For example, a recent study involving multiple international research groups published bioactivity data from screening a 400 compound library in a wide variety of assays against an array of diseases (van Voorhis et al. 2016). Indeed, that study screened the entire library in 236 different bioassays targeting multiple life cycle stages of the malarial parasite, 16 different protozoal parasites, 7 helminths, 9 bacterial and mycobacterial species, the dengue mosquito vector and the 60 human tumour cell lines of the NCI60 human cell line panel. Furthermore, toxicological, pharmacokinetic and metabolic properties were also 
determined, allowing the researchers to select the most promising drug candidates in the library for future studies. That study was a massive undertaking which was completed over a 2-year period. Whilst 55 different research groups were involved in that study, this does not detract from the vast amount of work the group undertook and their valuable findings.

It is noteworthy that despite the intended use of a single drug to target a single aspect of a disease, most drugs are not administered alone as a pure compound. Instead, the majority of drugs are combined with excipients to stabilise the drug, and to provide a format for effective drug delivery (Airaksinen et al. 2005). Although generally not directly affecting the drug target, excipients may confer indirect therapeutic enhancements to the drug's efficacy by facilitating its absorption, reducing viscosity or enhancing solubility, thereby increasing the drug's bioavailability. To avoid confusion, for the purposes of this commentary, a monotherapy is classed as a single drug, whether or not an excipient is involved.

\section{SUPPORT FOR MONOTHERAPIES}

The use of drug monotherapies may be driven as much by circumstance and regulation as by the efficacy of the treatment. The majority of drug researchers tend to focus their efforts on testing single compounds against a single target in the discovery phase of their research. This allows them to not only test the in vitro and/or in vivo efficacies of the drug, but to examine the events and pathways affected by the drug to determine what other effects (if any) may also occur. This process may either be relatively simple, or may be complex depending on the drug tested and the bioactivity examined. For example, if a novel compound is tested for antiinflammatory activity and a positive result is detected, the next step often is to determine what processes are affected by that compound. Does it block COX-2? Does it down-regulate the production of pro-inflammatory cytokines? Or up-regulate anti-inflammatory cytokines? Does it affect macrophage function? etc. For anti-inflammatory drug research, this may be laborious due to the complexity of the immunological triggers and inflammatory cascades which occur. However, if a mixture of compounds is initially examined, the researcher cannot readily determine which compound(s) is/are producing the desired effect(s) and which are producing any unwanted side effects. Thus, it is generally best to examine the effects of single compounds when evaluating the mechanisms of drug action.

Drug discovery studies may also begin by testing relatively crude mixtures of compounds. Indeed, this approach is commonplace during the search for new drugs from natural sources. An extract (or other preparation such as an essential oil) is prepared, and tested 
for a bioactivity relevant to, the disease state of interest. Studies such as these are generally a starting point for drug discovery. If a medicinally important bioactivity is detected, this mixture may become a useful medicine in its own right. However, the level of claims that can be made and the ability for the drug to be registered with drug regulatory authorities may be hampered due to the complexity of the drug. Instead, most studies of complex mixtures and/or traditional medicines are best viewed as stepping stones along the path towards the discovery of a new drug. These studies determine whether the crude preparations warrant further study. Chemical evaluations and/or bioactivity-driven separations, or metabolomics studies, may then be used to isolate and identify the active moieties. These can then be tested for bioactivity, efficacy, toxicity and mechanism of action by the same means as those in studies starting from a pure compound.

Targeting cell surface receptors has been a particularly effective method of developing new drugs. Cell surface receptors allow extracellular events to elicit intracellular changes. Cellular proliferation, differentiation, cell death, neuro-transmitter/hormone release and activation/inhibition of gene expression are all controlled by signal transduction pathways. Arguably, the most important of these cell surface receptors are the G-protein coupled receptors (GPCRs). A huge variety of molecules (amino acids, hormones, growth factors, ions, peptide and non-peptide neurotransmitters and polyphenolics) can bind externally to these receptors. The tissue specific expression of individual GPCRs, combined with the availability of highly specific ligands, makes these receptors attractive targets for the development of new drugs. Much research has targeted the GPCRs and numerous effective therapies have resulted from these studies. Ligands targeting specific GPCRs have led to effective therapies for a wide array of diseases including allergy and asthma, hypertension, anxiety and depression, pain, bronchitis (and other respiratory diseases), migraine, schizophrenia, glaucoma, nausea etc. Indeed, several of the top selling drugs act exclusively by targeting GPCRs. The GPCR targets, disease indications and some of the drugs developed have been reviewed previously (Nambi and Aiyar 2003). What these drugs have in common is that they are generally quite specific for a target receptor. This specificity may decrease side effects as well as reducing the cross-reactivity of the drug.

Ultimately, drug companies undertake research with the primary goal of developing a drug which will be financially lucrative. Drug development is a time-consuming and expensive process, with no guarantee that a drug will eventually attain approval for clinical applications. Following the discovery/development of a new chemical entity, it is tested for efficacy and 
toxicity in vitro and in animal trials. Following this, to be registered with the drug regulatory authorities, the drug must undergo three phases of clinical trials:

- Phase 1: The drug is tested against a small pool of healthy volunteers to determine toxicity.

-Phase 2: The drug is tested for both efficacy and toxicity against a much larger sample pool. Many drugs fail phase 2 trials due to lower than expected efficacies.

- Phase 3: The drug is tested in double blinded, placebo controlled trials to ensure efficacy. These trial may involve hundreds (or even thousands) of participants and can be very expensive.

This process is time-consuming and generally requires $10-15$ years to complete. It is also expensive. Although the costs of the trials will depend on the type of drug being evaluated, US\$1-1.5 billion is standard to take a drug to the completion of phase 3 trials. It has been estimated that 50\% of Phase 3 drugs are unsuccessfull (Arrowsmith 2011). Given the huge investments in time and money, drug companies inevitably advance the drugs and research lines which they believe have better chances of successful outcomes. As these outcomes are governed by regulatory authorities such as the US Food and Drug Administration (FDA), these authorities therefore indirectly influence the focus of research and the types of drug therapy that pharmaceutical companies develop. Monotherapy drugs may possess fewer side effects than drug combinations and may also be less cross-reactive/toxic. Thus, they will have a greater chance of successful passage through clinical trials and subsequent registration as drugs. As such, pharmaceutical companies have a far greater emphasis on developing monotherapy drugs. Furthermore, if a combinational therapy needs to be developed at a later time to increase therapeutic efficacy, this becomes an easier process if the active component is already registered.

\section{SUPPORT FOR COMBINATIONAL THERAPIES}

"This is the essence of the whole. It is always transcendent to its parts, and its character cannot be inferred from the character of its parts"

Jan Smuts: Prime Minister of South Africa 1939-1948 and pioneer of holism.

New clinical therapies most frequently comprise monotherapies, at least in part because drug research and regulation is most commonly geared towards developing “one drug, one target” 
therapies. However, over a period of usage, these monotherapies may be refined to provide greater efficacy. The evolution of treatment modalities from monotherapies to combinational therapies for HIV and leprosy provide good examples of therapeutic evolution and are discussed in more detail below. For both of these diseases, the development of drug resistance drove the development of new therapies with far greater efficacy than the original treatments. Combinational HIV therapies have proven particularly successful and with timely treatment, the patient often will often not progress to ‘full blown’ AIDS.

Alternatively, the development of combinational therapies may also develop from a need for greater efficacy, rather than due to resistance. Combinational therapies are now common for cancer therapy and often contain compounds that act via different mechanisms or target different aspects of the disease. These compositions may act via additive or synergistic interactions, greatly increasing the efficacy of the treatment. This may also have added benefits as the increased efficacy may allow lower therapeutic doses to be used. Cancer chemotherapies can be toxic to the patient, may have multiple side effects and may inhibit the immune system, thereby increasing patient susceptibility to other diseases. Thus, the ability to use lower chemotherapeutic doses may decrease the incidence of toxicity.

Similarly, multi-component/combinational therapies are now common for patients with coronary artery disease (CAD) and for the control of hypertension. Such patients are often coadministered with aspirin, a statin and one or more anti-hypertensive agent (beta-blockers and ACE inhibitors). Each of these drugs has documented indications against various aspects of cardiovascular disease. Such combinational therapies have been associated with reduced mortality and significant reductions in vascular events including myocardial infarction, ischemic cerebrovascular accidents (stroke), composite vascular endpoint and vascular mortality (Lafeber et al 2013). Such treatments have generally been administered as separate but concurrent therapies and have had varying degrees of success, often attributed to patient compliance. The development of a "polypill” therapy to treat CAD has long been proposed as a way to increase patient adherence with the treatment regimen. Recently, the European Union drug regulatory authorities approved the use of the drug Trinomia (a combination of acetylsalicylic acid, atorvastatin calcium tryhidrate and Ramipril) for administration as a single capsule (Public Assessment Report 2014).

The causative pathogen may not immediately be readily apparent for some infectious diseases and they may in fact be poly-microbial. Treatment with a single antibiotic may only affect some of the microbial pathogens within a population, allowing others to flourish. Thus, antibiotic cocktails may be preferred to provide extra protection. Even for a single bacterial 
species, multiple resistance profiles may occur and treatment with an antibiotic cocktail is often used against serious pathogens to increase the likelihood of eradicating the pathogen(s).

\subsection{Combinational therapies against pathogenic diseases}

Combinational therapies can offer several advantages over the single drug therapy models used for some diseases. These advantages are particularly evident for pathogenic diseases. Our historical reliance (despite the advice of giants in the field of microbiology) on single drug therapies to treat bacterial infections has been an important contributor to the development of bacterial resistance to antibiotic therapies. In his Nobel Prize speech in 1945, Alexander Fleming highlighted his growing concerns about bacterial resistance to antibiotics and cautioned restraint and more considered therapeutic use:

"The thoughtless person playing with penicillin treatment is morally responsible for the death of the man who succumbs to infection with the penicillin-resistant organism."

Alexander Fleming Nobel laureate in his 1945 address

True to his prediction, penicillin resistance was reported shortly after the wide-scale introduction of penicillin for clinical use. Similarly, bacteria have developed resistance to many other commonly used antibiotics (Cheesman et al 2017). Currently, the increase in bacterial resistance to antibiotics greatly outpaces our ability to develop new antibacterial chemotherapies. Within the last couple of years, totally resistant strains of Klebsiella pneumoniae and Neisseria gonorrhoea have been reported. There are no current chemotherapeutic options for the treatment of these pathogens and new therapies are desperately needed. Interestingly, it has long been recognised that the development of antibiotic resistance occurs substantially less frequently when antibiotic combinations are used rather than for single drug therapies (Weight et al 1953). This is particularly true if the combination contains drugs which act via different mechanisms. A bacterium may evade the actions of one antibiotic, although it is substantially less likely to evade several antibiotics with different cytotoxic mechanisms (Table 1). Thus, if newly discovered antibiotics were used in combination with other antibiotics since their clinical release, the development of antibiotic resistance would have been far less likely and many of the previously useful antibiotic drugs may still be effective. Antibiotic therapy targeting Mycobacterium leprae for the treatment of leprosy has long used antibiotic combinations (often containing relatively high doses of 
dapsone, rifampicin, ofloxacin and minocycline). The World Health Organisation (WHO) states that these drugs should never be used alone as monotherapies for leprosy to slow or prevent the bacterium developing resistance to them (WHO 2018a). To date, this approach has been effective and no $M$. leprae strains resistant to these antibiotic combinations have yet been reported.

However, it is perhaps naive to believe that all bacteria would have remained sensitive to antibiotics if medical science had employed the combinational approach from the time that penicillin was introduced clinically. There are numerous other ways in which bacteria are exposed to sub-lethal levels of antibiotics in their environment through their widespread usage in industrial and agricultural processes. Ideally, we should learn from our past mistakes and use any newly-released antibiotics much more cautiously and sensibly. Even when bacteria do develop antibiotic resistance, drug combinations may be useful to overcome these resistances and allow the antibiotic to function effectively again (Table 1). One way in which bacteria develop antibiotic resistance is to produce enzymes which inactivate the antibiotic. In response to the misuse of $\beta$-lactam antibiotics over an extended period of time, many bacterial strains have evolved to produce $\beta$-lactamase enzymes which cleave the $\beta$-lactam ring structure of these antibiotics, rendering them ineffective (Cheesman et al. 2017; Worthington and Melander 2013). Clavulanic acid is a weak fungal-derived ß-lactam compound with negligible intrinsic antimicrobial activity despite sharing a similar $\beta$-lactam ring to other $\beta$-lactam antibiotics. The similarity in chemical structure allows the molecule to bind and inhibit $\beta$-lactamase irreversibly. An antibiotic chemotherapy named Augmentin ${ }^{\circledR}$ (combination of amoxicillin and potassium clavulanate) is formulated to take advantage of these synergistic combinational effects and has effectively repurposed $\beta$-lactam antibiotics for use against $\beta$-lactam resistant bacteria. Similarly, carbapenems become useful again against carbapenem resistant bacteria when they are used in combination with imipenem metallo $\beta$-lactamase (IMBL) inhibitors (Cheesman et al 2017; Ahmed et al 2014).

Perhaps the most common method that bacteria use to develop antibiotic resistance is through the use of efflux pumps. These efflux pumps are utilised to rapidly remove antibiotics that have entered the bacterial cells, thus rendering them resistant to the effects of the antibiotic. Many bacterial efflux pumps are effective against multiple antibiotics and a single pump can allow the bacteria to evade the effects of various types of antimicrobials. If the actions of the pumps are inhibited, the intracellular concentration of antibiotic will increase, thereby allowing treatment to once again be effective. Several plant-derived compounds have been reported to 
be effective inhibitors of bacterial efflux pumps (Cheesman et al 2017; Worthington and Melander 2013). Despite this, there are no antibiotic-efflux pump inhibitor drug combinations in widespread clinical usage to date.

Combinational therapies also provide greater efficacy than monotherapies for the treatment of protozoal diseases and inhibit the development of further resistance (Table 1). The most wide spread use of anti-protozoal combinational therapies are the artemisinin-based combinational therapies (ACTs) used to treat malaria. These therapies combine fast acting artemisinin derivative drugs (e.g. dihydroartemisinin, artesunate, artemether) with an antimalarial drug from a different class (e.g. lumefantrine, mefloquine, sulfadoxine/pyrimethamine, piperquine, chlorproguanil/dapsone). ACTs have substantially greater efficacy than monotherapies, are faster acting and reduce the likelihood of the parasite developing resistance (Mutabingwa 2005). Indeed, the WHO state:

"Artemisinin and its derivatives must not be used as oral monotherapy, as this promotes the development of artemisinin resistance."

WHO website (http://www.who.int/malaria/areas/treatment/overview/en/). Cited 14 January 2018

Furthermore, combinations of one (or more) known active compounds with compounds which are inherently inactive by themselves, but which potentiate the activity of the active components, may increase the activity of the therapy and may even 're-activate' drugs to which $P$. falciparum are currently resistant. Extracts of the original plant from which the bioactive component was isolated may provide clues for the next round of malaria therapeutics. For example, Artemisia annua L. infusions used for anti-malarial therapy in TCM often contain only one fifth of the artemisinin required to achieve the same effect using artemisinin monotherapy (Ginsburg and Deharo 2011). A. annua infusions contain other compounds which greatly potentiate the activity of artemisinin and five particularly interesting flavonoids have been identified in A. annua infusions (artemetin, casticin, chrysoplenetin cirsilineol, chrysosplenol-D) (Ginsburg and Deharo 2011). Interestingly, these compounds are inherently inactive alone, yet each of them substantially potentiate the activity of artmesinin. Therefore, it is possible that the next "wonder drug” to replace the current gold standard antimalarial drug (artemisinin) may be artemisinin in combination with one or more of these potentiators. Such a combination would increase the effects of artemisinin and restore its efficacy against resistant strains of the parasite. Similarly, alkaloids isolated from Cicchona spp. bark (quinidine, 
cinchonine, cinchonidine) potentiate the activity of quinine (also isolated from Cicchona spp. bark) and thereby may make quinine effective again, even against quinine resistant strains. Surprisingly, studies examining such combinational effects are under-represented in malarial research and much more work is warranted.

Prospecting for new anti-malarial drugs from plant sources has proven very effective and has contributed greatly to the discovery of new antimalarial drugs, both directly and through the development of potent semi-synthetic analogues. However, surprisingly few of these studies have compared the biological activity of the purified compounds to the activity of the crude extracts from which they were obtained. For example, the Eskitis Institute for Cell and Molecular Therapies at Griffith University, Australia has screened >200,000 compounds purified from 40,000 plant and animal samples from Australia, Papua New Guinea and China for anti-malarial activity, but have not compared their effects to the crude extracts from which they were purified (reviewed by Ginsburg and Deharo 2011). The aim of those studies was to screen for new bioactive drug leads to focus further study and the program has been very effective in that respect. However, it is likely that many synergistic combinations may have been missed and opportunities to develop synergistic combinational therapies have been overlooked. Perhaps future studies could revisit these earlier screenings with the aim of searching for potentiator compounds.

Drug combination therapies are also used for the treatment of some viral diseases. The use of combinations in HIV therapy is particularly prevalent. The first effective HIV chemotherapy used the nucleoside reverse transcriptase inhibitor zidovudine (AZT) to inhibit the viral reverse transcription. However, the HIV-1 reverse transcriptase enzyme has since developed a proofreading function similar to that of eukaryotic DNA polymerase, rendering AZT ineffective against that strain of the virus. Recently, the management of HIV has evolved to use combinations of antiretroviral drugs (Adams et al 2004). Typically, these combinations consist of at least 2 nucleoside reverse transcriptase inhibitors, combined with 1 non-nucleoside reverse transcriptase inhibitor, or protease/integrase inhibitors. These combinations not only provide patients with substantially greater efficacies and better therapeutic outcomes than with HIV monotherapies, they also inhibit the development of resistance of the HIV virus to chemical treatments by suppressing HIV replication to a very low rate. These combinational HIV therapies have been so effective that in many parts of the world, HIV has become a chronic condition which often does not progress to AIDS. Thanks in a large part to these combinational therapies, we may soon reach a time when medical science can claim that the HIV epidemic is under control. 
"With collective and resolute action now and a steadfast commitment for years to come, an AIDS-free generation is indeed within reach"

Anthony Fauci, United States National Institute of Allergy and Infectious Diseases, 2012

\subsection{Combinational therapies against cancer}

Combinational therapies are relatively common-place for cancer treatment. Combining cancer therapeutics often enhances the efficacy of the treatment compared to the individual monotherapies, particularly when the individual chemical entities target different pathways (Table 1). In such combinations, the individual components may act in a synergistic or additive manner, thereby lowering the therapeutic dosage of each individual drug required. This has the added benefit of decreasing the overall toxicity of the therapy as the toxicity is less likely to also be additive when the drugs target different cellular pathways. Furthermore, constant treatment with a monotherapy drug often induces cancer cells to adopt alternative pathways to bypass the drug's effects. When multiple pathways are targeted by a combinational therapy, the cells are less likely to adapt to overcome the actions of all drugs in the combination. Therefore, monotherapies are substantially more susceptible to drug resistance than are combinational therapies. For example, sabutoclax (a pan-Bcl-2 inhibitor) and minocycline act synergistically on the intrinsic apoptotic pathway (Quinn et al 2015). Alternatively, combining cancer drug(s) with drugs with a high antioxidant capacity often substantially increases the efficacy of the therapy by inducing upregulation of Nrf2 and its translocation to the nucleus, thereby inducing apoptosis (Mokhtari et al 2017).

Some cancer cells develop resistance to cancer monotherapies by over-expressing ATPbinding cassette (ABC) transporters that pump chemotherapeutics out of the cell, thereby lessening their effects. A recent study examined the comparative effects of doxorubicin monotherapy and combinations of doxorubicin and methylene blue (in conjunction with photodynamic therapy) towards doxorubicin resistant JC cells (mouse mammary adenocarcinoma) (Khadir et al 2010). The authors reported that the combination was substantially more potent than doxorubicin monotherapy. When treated with doxorubicin alone, the JC cells up-regulated the expression of an ATP-binding cassette pump which eliminated the drug from the cell and made it resistant to the drug's effects. Inclusion of the methylene blue and photodynamic therapy in the treatment modality inhibited the function of 
the ATP-binding cassette and enhanced the accumulation of doxorubicin in the cells. This ultimately resulted in substantially enhanced therapeutic outcomes in fewer cycles.

Prolonged chemotherapy treatment may induce epigenetic alterations (e.g. methylation), making cancer cells prone to developing resistance to chemotherapy. Chemotherapies containing anticancer drugs in combination with drugs that reverse epigenetic alterations may reverse the acquired genetic changes. For example, the epigenetic drug decitabine can reactivate genes by reversing DNA methylation (Strauss and Figg 2016). When used in combination with carboplatin, decitabine restores carboplatin sensitivity in ovarian cancer cells (Matei et al 2012). Demethylation of key genes including GAS1, TIMP4, 1CAM1 and WISP2 allowed their expression by the ovary cancer cells and it is believed that this reexpression is responsible for the restored carboplatin sensitivity.

Carbonic anhydrase (CA) is upregulated in some cancers to adapt to hypoxic stress by regulating cellular $\mathrm{pH}$. Thus, therapies targeting $\mathrm{CA}$ may inhibit cancer growth and progression. Combinations of carbonic anhydrase inhibitors (CAI) and other anticancer drugs such as sulforaphane (SFN) provide far superior cytotoxic activity than the individual drugs when used as monotherapies. SFN down-regulates the expression of Bcl-2 (anti-apoptotic gene), thus inducing apoptosis. However, SFN degradation increases as the $\mathrm{pH}$ decreases (Franklin et al 2015). Inhibiting the activity of carbonic anhydrase maintains cellular pH levels within the $\mathrm{pH}$ range that SFN requires to function optimally. Therefore, the effects of SFN are substantially potentiated when used in combination with CAIs against some cells (e.g. MCF-7 human breast cancer cells) (Mokhtari et al 2017).

Cancer cells may also develop resistance to checkpoint inhibitors, rendering them ineffective as cytostatic therapies. The use of combinations of checkpoint inhibitors and drugs that prevent cancer cells from inactivating $\mathrm{T}$ cells is quite new but has already proven itself to be an effective therapeutic option. Immunotherapies in combination with checkpoint inhibitors may counteract the development of resistance and these combinations have been shown to be effective in checkpoint resistant melanomas and breast cancer tumours (Neubauer 2017). However, combinational therapies of this type have limitations. Combinations containing many of the antibodies utilised in these early studies (e.g. ipilimumab) have significant toxicity, which limits their clinical use. Furthermore, these immuno-therapies are very expensive, further limiting their clinical use. However, this is still a new field and it is likely that cheaper, effective antibodies with lower toxicity will be developed in the future. When/if this occurs, 
combinations of checkpoint inhibitors and cytotoxic drugs may prove to be a viable alternative to current therapies.

\subsection{Combinational therapies to treat inflammation}

Drug combinations are often also useful in treating some inflammatory conditions and there are numerous studies reporting enhancement of the effects of anti-inflammatory drugs by using combinational therapies. The corticosteroid budesonide and the long-acting $\beta_{2}$ adrenergic receptor agonist salmeterol are both effective drugs for the maintenance and prevention of asthma symptoms when used individually. However, a combination of these two drugs is substantially more effective against several inflammatory markers of asthma (Pappová et al 2016). The levels of TNF- $\alpha$, IL-4, IL-5, IL-13 and GM-CSF were markedly decreased compared to the levels seen for budesonide and salmeterol monotherapies alone. The decrease in TNF- $\alpha$ levels for the combination was particularly noteworthy. The authors of that study attributed this decrease to a combination of the two different mechanisms used by these drugs. Budesonide induces the expression of proteins which degrade TNF- $\alpha$ mRNA, whereas salmeterol directly suppresses TNF- $\alpha$ synthesis via cAMP dependent activation of guanine nucleotide exchange protein (Epac1). Combinations of immunotherapy drugs (e.g. infliximab, adalimumab) with an immunomodulator (e.g. azathioprine) optimise the pharmacokinetics of the drug, minimise immunogenicity and substantially improve the efficacy of the treatment compared to monotherapy (Sultan et al 2017).

Auto-immune inflammatory diseases are particularly suited to combinational therapies. These are complex diseases which consist of multiple phases. For example, it has been proposed that rheumatoid arthritis consists of three major phases, which each comprise multiple steps (Cock 2014):

- Antigenic trigger phase. Microbial or environmental antigens interact with the immune system. Therapies targeting the microbial triggers or avoiding the environmental triggers can block the disease etiology and therefore block the downstream effects. Macrophage activation results in the release of chemo-attractants which induce neutrophil and monocyte movement and these processes can also be targeted.

- Immune phase. Multiple events occur. Interaction between the antigenic disease progenitor and the immune system establishes an immune response. Antigen-presenting cells are activated, antibodies are produced etc. In susceptible people, the antibodies bind self tissue, resulting in tissue degradation and the onset of inflammation. 
- Inflammatory phase. Inflammatory cascades are activated, TNF- $\alpha$, cytokines, chemokines, acute phase proteins, complement cascade components, vasoactive amines etc. are produced and released.

Thus, autoimmune inflammatory diseases have numerous events available as chemotherapy targets. Combinations of drugs targeting several events in the disease progression are particularly effective. For example, combinations of the immunosuppressive drugs cyclosporine and methotrexate are effective in reducing the symptoms of severe rheumatoid arthritis (Tugwell et al 1995). Similarly, combinations of methotrexate with either sulfasazine, chloroquine, leflunomide, doxycycline or gold are also effective combinational therapies (Dale et al 2007). Despite these successes, much work is required in developing effective combinations for the treatment of autoimmune inflammatory diseases.

\section{PLANT EXTRACTS AND OILS FOR THE TREATMENT OF INFLAMMATION}

Inflammation is a complex response by the body to injury and/or infection. It typically follows a variety of insults including burns, wounds, bites and stings etc. It is characterised by a wide variety of symptoms including:

- Swelling. Injury may result in increased capillary permeability which allows leukocyte migration and fluid accumulation in the damaged tissue. This accumulation results in the swelling characteristic of inflammation.

- Redness and heat are caused by vasodilation, reducing blood pressure and increasing circulation.

- Pain is a complex reaction resulting from the release of short peptides and prostaglandins.

Many of these effects are the result of vasodilation and increased membrane permeability, allowing leukocyte migration and fluid accumulation.

The inflammatory process involves the cellular release of several classes of molecules. Vasoactive substances (eg. bradykinin, prostaglandins and vasoactive amines) dilate blood vessels, opening junctions between cells to allow leukocytes to pass through capillaries. Any compound capable of blocking these vasoactive substances would potentially affect the symptoms of inflammation. Chemotactic factors including several proteins and peptides are 
required to increase cell motility, especially the motility of leukocytes during inflammation. Blocking these chemotactic factors or blocking their effects prevents inflammatory swelling. Thus, combinational therapies may be particularly effective against inflammation and inflammatory diseases as they can potentially target the disease etiology, as well as several phases of the disease progression concurrently.

Plants have been used therapeutically for thousands of years and continue to be the main treatment modality for a large percentage of the world's population. Although their usage is often viewed with scepticism by Western medicine, their usage is increasing globally as complementary (and sometimes alternative) treatments, in conjunction with allopathic medicine. Plant therapies are particularly suited as therapeutics against complex inflammatory diseases. Many plant medicines affect several phases of inflammatory disease progression, from blocking the antigenic triggers, to modulating the immune response, to directly affecting inflammatory cascades. For example, aspirin, which is derived from salicylic acid from the bark of Salix spp., has analgesic affects and alleviates the pain associated with inflammation. It also has multiple effects on several inflammatory pathways. It inhibits cyclooxygenase activity and therefore decreases prostaglandin levels. It also inhibits several pro-inflammatory signalling pathways via inhibition of $\mathrm{NF}-\kappa \mathrm{B}$, and also reduces polymorphonuclear leukocyte and macrophage migration (Morris et al 2009).

With increasing awareness of well-established Eastern medicine systems such as Ayurveda and Traditional Chinese medicine (TCM), the use of medicinal plants to treat chronic inflammatory diseases such as rheumatoid arthritis, inflammatory bowel disease and multiple sclerosis is increasing. These plants contain complex mixtures of secondary compounds and are essentially crude combinational therapies in their own right. However, there are notable differences between defined pharmaceutical combinations and medicinal plant formulations/natural products. For pharmaceutical combinations, pharmacological research screens for multiple differentiable and known pharmacological responses. In contrast, for medicinal plant formulations, the screening and clinical trial process generally looks for a single hybrid outcome (e.g. anti-inflammatory activity) without necessarily knowing which constituent(s) within the mixture is/are responsible for that outcome. Therefore, the pharmacology of each of the individual ingredients of a pharmacological combination are generally well established, whereas this is not necessarily true for medicinal plant formulations and indeed, we often do not know how many active ingredients are present in these formulations, nor which are responsible for the individual pharmacological effects. 
A number of plant species are extremely well known for this purpose and have been used in multiple traditional healing systems. For example, Allium sativum L. (garlic) and Aloe vera (L.) are naturalised globally and are so widely used therapeutically that it is no longer certain where their medicinal use originated. Table 2 lists some plants with well-established uses in traditional medicine to treat inflammation. This listing is not exhaustive and instead only lists some of the better known examples of the anti-inflammatory plants. These will not all be discussed individually for the sake of brevity and indeed some of these plants have been thoroughly reviewed previously (Biswas 2002; Cock 2015a; Cock 2015c). Instead, I will focus my discussion on a couple of the more extensively studied species.

\subsection{The anti-inflammatory effects of Aloe vera}

A. vera leaf extracts have been reported to have both good immunostimulant and immunosuppressant activities (as reviewed by Cock 2015a). Whilst numerous A. vera components are known to be immunostimulants, the immune-modulatory properties of acemannan have been particularly well studied. Acemannan activates macrophage cells and induces antigen processing. The activated macrophages secrete cytokines including IL-1, IL6, interferon, GM-CSF and TNF- $\alpha$, which subsequently induce inflammation. Acemannan also further enhances macrophage sensitivity to IFN- $\gamma$, subsequently inducing apoptosis. Neither acemannan nor IFN- $\gamma$ alone are capable of inducing apoptosis. Both are required and this synergistic effect appears to function by inhibiting the expression of Bcl-2 proteins. A number of smaller Aloe vera polyphenolic compounds also have immune-modulatory activity. Aloe emodin and other anthraquinone derivatives reduce IL-1, IL-2 and IL-2 receptor expression.

Inflammation requires the cellular release of several classes of molecules. Vasoactive substances (e.g. bradykinin, prostaglandins and vasoactive amines) dilate blood vessels, opening junctions between cells to allow leukocytes to pass through capillaries. Any compound that can block/inhibit these vasoactive substances could reduce the impact of inflammation $A$. vera is rich $\beta$-sitosterol which blocks the release of PGI2 and prostaglandin E2 (PGE2) from macrophages, thereby reducing vasodilation (as reviewed by Cock 2015a). A. vera leaf chromones inhibit cyclooxygenase-2 (COX-2) and thromboxane $\mathrm{A}_{2}$ synthesis and therefore have anti-inflammatory effects. In contrast, anthraquinones have been shown to stimulate PGE2 release and may have pro-inflammatory effects. Inhibiting the release of chemotactic factors which increase cell motality (especially the motility of leukocytes during inflammation), or blocking their effects, prevents inflammatory swelling. Several compounds 
in A. vera extracts are able to block chemotaxis. A. vera anthraquinones inhibit cytokine production and IL-2 mRNA expression in activated T lymphocytes, thereby decreasing chemotaxis. More recent studies have demonstrated that aloe emodin decreases plasma levels of the cytokines IL-2 and TNF- $\alpha$ whilst increasing IL-10 (which itself down-regulates IL-2 and TNF- $\alpha$ cytokine activity). Therefore, $A$. vera contains multiple molecular entities that target different phases of inflammation. Whilst there is a paucity of studies comparing the activity of the individual components to that of crude extracts, it is likely that the combined effects of these components is greater than the activity of the individual components. Studies are required to confirm this.

\subsection{The anti-inflammatory activity of Curcuma longa (turmeric)}

Tumeric is used in Ayurveda to treat inflammation, cancer, cardiovascular and gastrointestinal disease. Curcumin is the compound believed to be responsible for the anti-inflammatory activity of this plant. This compound has a myriad of effects related to its anti-inflammatory properties (reviewed in Jurenka 2009). Briefly, curcumin:

- Inhibits COX-2 and therefore decreases the production of prostaglandins, prostacyclins and thromboxanes. Several prostanoids have powerful pro-inflammatory effects. $\mathrm{PGI}_{2}$ and $\mathrm{PGE}_{2}$ are powerful vasodilators. Inhibiting their production therefore inhibit the migration of leukocytes out of blood vessels into the surrounding tissue.

- Inhibits the metabolism of arachidonic acid by lipoxygenase and the scavenging of free radicals generated. It also inhibits the activity of glutathione-S-transferase.

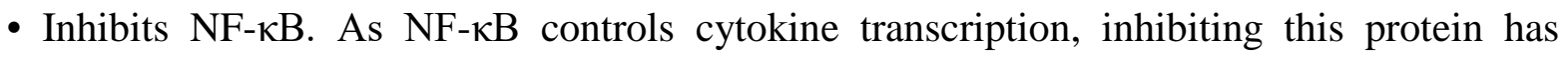
profound effects on inflammatory pathways and decreases the levels of pro-inflammatory cytokines. NF- $\mathrm{kB}$ also regulates some genes responsible for both the innate and adaptive immune response and therefore also down-regulates the immune system.

- Decreases expression of the pro-inflammatory cytokines TNF- $\alpha$, IL-1 $\beta$, IL-6. As these cytokines mediate the innate immune response, decreased levels lessen the effects of inflammation.

- Downregulates enzymes (including protein kinase C) which mediate inflammation. 
Therefore, curcumin targets multiple aspects of inflammation and is a particularly effective anti-inflammatory monotherapy. However, the usefulness of curcumin clinically is currently hampered by its relatively low solubility and bioavailability. There is substantial recent focus on increasing the bioavailability of curcumin through combination with carriers and via the production of curcumin nano-formulations with improved bioavailability (reviewed in Jurenka 2009).

Whilst most of the focus has been on curcumin, crude turmeric extracts also have good anti-inflammatory activity and have been reported to inhibit cyclooxygenase, 5-lipoxygenase and glutathione-S-transferase activity (Ramadan et al 2011). Furthermore, turmeric also lowers histamine release (Akram et al 2010). Interestingly, few studies have compared the activity of the pure curcumin to that of crude turmeric extracts, so it is unknown whether there is an added benefit of using curcumin in an extract (combinational therapy) form.

\subsection{The anti-inflammatory activity of Boswellia spp. (frankincense)}

Multiple Boswellia spp. are used in traditional healing systems, including B. carterii, B, sacra, B. serratia. All are known for a wide array of therapeutic properties, including anticancer and antibacterial activities. Extracts from some species also have strong anti-inflammatory activity, which is mediated via inhibition of TNF- $\alpha$, PGE2, IL-2, IL-1 $\beta$, NO, MDA and MAP kinase (Su et al 2015; Gayathri et al 2007; Banno et al 2006). A recent study demonstrated that aqueous frankincense extracts and essential oils also inhibited COX-2 ( $\mathrm{Li}$ et al 2015). The same study reported that $\alpha$-pinene, linalool, and 1-octanol were major components of the extract and oil and tested the isolated compounds and reported that each inhibited COX-2 when tested alone. However, when recombined, the mixture of these three compounds was a substantially superior inhibitor of COX-2 than the sum of the compounds tested alone, highlighting the potential in developing a combinational therapy.

\subsection{The anti-inflammatory effects of Harpagophytum procumbens (Devil's claw)}

$H$. procumbens roots are used in multiple traditional African medicine systems to treat pain and arthritis (van Wyk et al 2009). It also is effective in reducing inflammation and pain, and is established globally as an effective anti-inflammatory therapy. Aqueous $H$. procumbens extracts inhibit the expression of COX-2 and nitric oxide synthase (iNOS) enzymes, thereby 
suppressing PGE 2 and NO production (Jang et al 2003). The extracts did not significantly affect COX-1 expression, except when the cells were exposed to relatively high extract concentrations. Futhermore, the $H$. procumbens extract did not significantly affect cellular viability, indicating its suitability for clinical use. Unfortunately, the authors of that study did not state which part of the plant was tested, although it is assumed that it was the roots. More recent studies have confirmed and extended these findings. One study used $H$. procumbens root cultures grown under controlled sterile conditions to standardise the plant material examined and minimise the influence of external factors (Gyurkovska et al 2011). Methanolic extracts of the plant material were prepared and tested on murine macrophages for their effects on COX1 and COX-2 expression, as well as on NO, TNF- $\alpha$ and IL-6 release. The study confirmed that COX-2 and iNOS expression were significantly inhibited in the presence of the extract by approximately 70 and 40\% respectively. However, unlike earlier publications, the Gyurkovska study also reported that COX-1 expression was inhibited by a similar level to that of COX-2. The same publication reported substantial inhibition of NO, TNF- $\alpha$ and IL-6 by approximately $20 \%, 45 \%$ and $32 \%$ respectively compared to the untreated control. That study also isolated and investigated the activity of several extract components and determined verbascoside and harpagoside to be the major anti-inflammatory constituents of $H$. procumbens roots. Interestingly, whilst pure verbascoside and harpagoside were potent anti-inflammatory mediators, the crude extract was substantially stronger, indicating that the extracts may contain potentiating compounds that increase the efficacy of verbascoside and harpagoside. I am unaware of any studies that have screened for potentiating compounds in H. procumbens root extracts. However, this is an area that should be addressed in future. If/when these potentiators are identified, mixtures of verbascoside and/or harpagoside in combination with the potentiating compound in defined ratios could be prepared. These combinations may be particularly effective therapeutics and due to their defined compositions they may be suitable (following clinical trials) for drug registry and clinical use.

\section{CONCLUSIONS AND FUTURE DIRECTIONS}

Much of the expansive volume of drug discovery research globally is driven by the pharmaceutical industry's need to advance drugs that are likely to be accepted for clinical use. The pharmaceutical industry's focus is in turn driven by the requirements for relevant registration authorities such as the FDA. Not surprisingly, this has focussed much of both the 
pre-clinical and clinical research on the study of monotherapy drugs. Such drugs are validated in the pre-clinical research phase against a single definable therapeutic target. The in vitro and/or in vivo efficacy of the drug can be tested and the events and pathways affected can be examined. Furthermore, the new lead can also be examine for counter-indications, crossreactivity with other drugs and toxicity. A good understanding of the drug can be obtained prior to the researcher advancing it onto expensive and time consuming clinical trials. Such evaluations are often not as simple for combinations, where not only the identity of the components present is important, but their relative concentrations and ratios may also be crucial to the activity of the combination. It is not surprising that the pharmaceutical industry favours monotherapies and takes a pragmatic approach to drug development.

However, the activity of some monotherapies is not optimal and their safety and efficacy can often be improved. This has long been a cornerstone for cancer chemotherapy, where combinational treatments are commonplace, rather than the exception to the rule as they are for other diseases. Therefore, it is worth examining the reason(s) for the development of combination treatments for cancer. The use of combinations in cancer chemotherapy has largely been influenced by two major factors. The development of drugs with increased efficacy has driven much current research into new cancer therapies. This is particularly relevant as cancer cells develop resistance to many of the current cancer monotherapies. Toxicity is also a major issue with cancer chemotherapy and especially with monotherapy drugs. Cancer drugs often affect cellular pathways and targets that are common to both cancer cells and to normal cells and many cancer therapies have significant toxicity to individuals undergoing therapy. One major focus of research into new cancer therapies is that the therapy needs to be at least as effective (and preferably more effective) as current treatment regimens, yet have lower negative impacts (toxicity) on the patient. Combinations have proven to be extremely effective in this respect in a number of ways reviewed early in this commentary. No matter which format the combination takes, it will generally increase the efficacy of one or more bioactive components, thereby allowing the use of lower, less toxic concentrations.

It is noteworthy that, even when anticancer combination therapies are developed and used, these usually utilise combinations of chemical entities that have previously been through the clinical evaluation and registration process and generally, at least one component of the combination has previously been used for this purpose. The development of the combinational therapy is a downstream event following the establishment of the drug clinically. The focus of these therapies is therefore not to develop a new chemical entity, but rather to improve on that 
entity's efficacy and toxicity profile. The same is true for the development of other combinational therapies targeting very different diseases. I have highlighted several examples of compounds that are already used as anti-inflammatory drugs in this commentary and for some of these I have provided examples of combinations containing these entities, with substantially improved efficacies. Perhaps more interestingly, traditional plant based antiinflammatory drugs have potential to develop new, effective drugs. There are numerous examples for the development of anti-inflammatory drugs using combinations of plant compounds, although $H$. procumbens provides one of the most relevant examples. Verbascoside and harpagoside isolated from are H. procumbens roots are both potent antiinflammatory mediators when used alone. However, crude $H$. procumbens root extracts are substantially stronger. Screening $H$. procumbens extracts for compounds which potentiate the activity of verbascoside and/or harpagoside is warranted and may result in a substantially improved anti-inflammatory drug.

The development of antimicrobial combination therapies has also been driven by similar factors, especially the need to develop new, effective therapies as bacteria develop resistance to monotherapy antibiotics. The reactivation of some of our previously most versatile antibiotics ( $\beta$-lactams) by combining them with $\beta$-lactamase inhibitors such as clavulanic acid has highlighted the promise of combinational antibiotic therapies. Likewise, ACT to treat malaria and antiretroviral combinations to treat HIV have dramatically improved the outcomes for these diseases. As for cancer and inflammation, the use of combinations against these diseases was not the first option and monotherapies were initially used in all cases. Only when the monotherapy loses efficacy has the pharmaceutical industry looked to combinations for improved outcomes. It is unlikely that this situation will change, at least in the short term. However, it is perhaps worth considering that some drugs would be best not to be introduced clinically straight away as monotherapies, despite the requirement for the individual drugs to be evaluated and registered. In particular, it may be preferable to only release new antibiotics as combinations, rather than as monotherapies to decrease the likelihood of resistance to the drug and to safeguard its use into the future. A forward thinking approach such as this would undoubtedly have health, financial and social benefits reaching far into the future. Realistically, this is unlikely due to the pharmaceutical industry’s (understandable) need to get drugs approved and marketed to achieve a profitable bottom line.

Furthermore, pharmaceutical companies may have less interest in developing combinational therapies than monotherapies due to the extra hurdles imposed by drug 
regulatory authorities for the registration of combinational therapies. Before a combinational therapy will be considered by the US FDA, the applicant will need to meet all of the following criteria (US Department of Health and Human Services, 2013):

- The therapy must only be intended for use against serious/life threatening diseases and conditions.

- There must a strong biological rationale for use of the combination rather than mono-therapies (e.g. the different components target distinct aspects of the disease pathogenesis.

- Using the combination must be substantially more beneficial than a monotherapy approach (e.g. greater efficacy, lower toxicity, delayed resistance).

- There must be compelling reasons that the drug components are not developed independently. If all of these conditions are not met, the FDA will not consider the combinational therapy for registration, regardless of the efficacy of the combination. Any pharmaceutical company that takes a drug combination to clinical trials without satisfying these all of these conditions would essentially be wasting their time and money as the FDA would not consider the treatment, no matter its efficacy and safety.

Even when a combinational therapy is deemed appropriate for clinical trials, there are substantially more rigorous requirements for its evaluation than for monotherapy drugs. Not only does the efficacy and non-toxicity of the combination have to be demonstrated, but the individual components must also be evaluated separately. Likewise, clinical pharmacology studies (bioavailability, pharmacokinetics, renal/hepatic impairment, and drug interaction studies) must also be conducted an all individual components within the combination, as well as for the mixture. Thus, the pre-clinical and clinical trial processes are substantially more extensive, time consuming and expensive for combination drugs than for mon-therapies, representing a major disincentive to the development on combinational therapies. Whilst these requirements and the disparity between registering combination versus mono-therapies exist, pharmaceutical companies will favour the development of mono-component drugs, irrespective of efficacy, safety and social benefits of the combinational therapy.

\section{REFERENCES}


Adams BM, Banks HT, Kwon HD, et al (2005) Dynamic multidrug therapies for HIV: Optimal and STI control approaches. J Comput Appl Math 184(1):10-49.

Adel SPR, Prakash J (2010) Chemical composition and antioxidant properties of ginger root (Zingiber officinale). J Med Plant Res 4(24):2674-2679.

Ahmed A, Azim A, Gurjar M, et al (2014) Current concepts in combination antibiotic therapy for critically ill patients. Indian J Crit Care Med 18:310-314.

Airaksinen S, Karajalainen M, Kivikero N, et al (2005) Excipient selection can significantly affect solid-state phase transformation in formulation during wet granulation. AAPS Pharm Sci Tech 6: E311-322.

Akihisa T, Takahashi A, Kikuchi T, et al (2011) The melanogenesis-inhibitory, antiinflammatory, and chemopreventative effects of liminoids in n-hexane extract of Azadirachta indica A. Juss. (Neem) seeds. J Oleo Sci 60:53-59.

Akram M, Uddin S, Ahmed A, et al (2010) Curcuma longa and curcumin: A review article. R J Biol - Plant Biol 55(2):65-70.

Arrowsmith J (2011) Trial watch: phase III and submission failures: 2007-2010. Nat Rev Drug Discov. 10(2):87.

Babu NP, Pandikumar P, Ignacimuthu S (2011) Lysosomal membrane stabilisation and antiinflammatory activity of Clerodendrum phlomidis L.f., a traditional medicinal plant. J Ethnopharmacol 135(3):779-785.

Banno N, Akihisa t, Yasukawa K, et al (2006) Anti-inflammatory activities of the triterpene acids from the resin of Boswellia carteri. J Ethnopharmacol 107(2):249-253.

Biggs I, Sirdaarta J, White A, et al (2016a) GC-MS analysis of frankincense extracts which inhibit the growth of bacterial triggers of selected autoimmune diseases. Pharmacog Commn 6(1):10-22. DOI: 10.5530/pc.2016.1.3

Biggs I, Sirdaarta J, White A, et al (2016b) GC-MS analysis of Commiphora molmol oleo-resin extracts which inhibit the growth of bacterial triggers of selected autoimmune diseases. Pharmacog J 8(3):191-202. DOI: 10.5530/pj.2016.3.4

Biswas K, Chattopadhyay I, Banerjee RK, et al (2002) Biological activities and medicinal properties of neem (Azadirachta indica). Curr Sci 11:1336-1345. 
Byeon SE, Chung JY, Lee YG, et al (2008) In vitro and in vivo anti-inflammatory effects of taheebo, a water extract from the inner bark of Tabebuia avellanedae. J Ethnopharmacol 119:145-152.

Capasso A (2013) Antioxidant Action and Therapeutic Efficacy of Allium sativum L.. Molecules 18:690-700.

Carey AN, Fisher DR, Joseph JA, et al (2013) The ability of walnut extract and fatty acids to protect against the deleterious effects of oxidative stress and inflammation in hippocampal cells. Nutr Neurosci 16(1):13-20.

Cheesman MJ, Ilanko A, Blonk B, et al (2017) Developing new antimicrobial therapies: Are Synergistic combinations of plant extracts/compounds with conventional antibiotics the solution? Pharmacog Rev 11(22):57-72. DOI: 10.4103/phrev.phrev_21_17

Cock IE (2015a) The genus Aloe: Phytochemistry and therapeutic uses including treatments for gastrointestinal conditions and chronic inflammation. In Novel Natural Products: Therapeutic Effects in Pain, Arthritis and Gastro-intestinal Diseases, Progress in Drug Research 70; Rainsford KD et al. (eds.); Springer Basel:179-235.

Cock IE (2015b) The safe usage of herbal medicines: Counter-indications, cross-reactivity and toxicity. Pharmacog Commn 5(1):2-50. DOI: 10.5530/pc.2015.1.2

Cock IE (2015c) The medicinal properties and phytochemistry of plants of the genus Terminalia (Combretaceae). Inflammopharmacol 23(5):203-229. DOI 10.1007/s10787015-0246-z

Cock IE (2014) The early stages of rheumatoid arthritis: New targets for the development of combinational drug therapies. OA Arthritis 2(1):5.

Dale J, Alcorn N, Capell H, et al (2007) Combination therapy for rheumatoid arthritis: methotrexate and sulfasalazine together or with other DMARDs. Nat Clin Pract Rheumatol 3(8):450-458.

El SN, Karakaya S (2009) Olive tree (Olea europaea) leaves: potential beneficial effects on human health. Nutr Rev 11(1):632-638.

Feltonstein MW, Schühly W, Warnick JE, et al (2004) Anti-inflammatory and antihyperalgesic effects of sesquiterpine lactones from Magnolia and Bear’s foot. Pharmacol Biochem Behav 79(2):299-302. 
Franklin SJ, Dickinson SE, Karlage KL, et al (2014) Stability of sulforaphane for topical formulation. Drug Dev Ind Pharm 40(4):494-502.

Fu Y, Zhou H, Wang S, et al (2014) Glycyrol suppresses collagen-induced arthritis by regulating autoimmune and inflammatory responses. PLoS ONE 9:e98137.

Gayathri B, Manjula N, Vinaykumar KS, et al (2007) Pure compound from Boswellia serrata extract exhibits anti-inflammatory property in human PBMCs and mouse macrophages through inhibition of $\mathrm{TNF} \alpha$, IL-1 $\beta$, NO and MAP kinases. Int Immunopharmacol 7(4):473-482.

Grzanna R, Lindmark L, Frondoza CG (2005) Ginger - An herbal medicinal product with broad anti-inflammatory actions. J Med Food 8(2):125-132.

Gyurkovska V, Alipieva K, Maciul A, et al (2011) Anti-inflammatory activity of Devil’s claw in vitro systems and their active constituents. Food Chem 125(1):171-178.

Hernández-Ortega M, Ortiz-Moreno A, Hernández-Navarro MD, et al (2012) Antioxidant, antinociceptive, and anti-inflammatory effects of carotenoids extracted from dried pepper (Capsicum annuum L.) J Biomed Biotechnol Article ID 524019

Hodge G, Hodge S, Han P (2002) Allium sativum (garlic) suppresses leukocyte inflammatory cytokine production in vitro: Potential therapeutic use in the treatment of inflammatory bowel disease. Cytometry 48:209-215.

Jang MH, Lim S, Han SM, et al (2003) Harpagophytum procumbens suppresses lipopolysaccharide-stimulated expressions of cyclooxygenase-2 and inducible nitric oxide synthase in fibroblast cell line L929. J Pharmacol Sci 93:367-371.

Jurenka JS (2009) Anti-inflammatory properties of curcumin, a major constituent of Curcuma longa: A review of preclinical and clinical research. Alt Med Rev 14(2):141-153.

Khdair A, Chen D, Patil Y, et al (2010) Nanoparticle-mediated combination chemotherapy and photodynamic therapy overcomes tumor drug resistance. J Control Release 141:137-144.

Kim JH, Kim SJ (2014) Overexpression of microRNA-25 by withaferin A induces cyclooxygenase-2 expression in rabbit articular chondrocytes. J Pharmacol Sci 125:8390. 
Kim SJ, Sancheti SA, Sancheti SS, et al (2010) Effect of 1,2,3,4,6-penta-O-galloyl-beta- Dglucose on elastase and hyaluronidase activities and its type II collagen expression. Acta Pol Pharm 67:145-150.

Lafeber M, Spiering W, van der Graaf Y et al (2013) The combined use of aspirin, a statin, and blood pressure-lowering agents (polypill components) and the risk of vascular morbidity and mortality in patients with coronary artery disease. Am Heart J 166(2): 282-289.

Lebaratoux P, Sirdaarta J, Rayan P, et al (2016) An evaluation of the antibacterial, antiGiardial, anticancer and toxicity properties of selected nut extracts. Pharmacog Commn 6(3):174-184. DOI: 0.5530/pc.2016.3.7

Li XJ, Yang YJ, Li YS, et al (2016) $\alpha$-Pinene, linalool, and 1-octanol contribute to the topical anti-inflammatory and analgesic activities of frankincense by inhibiting COX-2. J Ethnopharmacol 179(17): 22-26.

Li XY, Zong SL, Chen FY, et al (2012) Three novel immunosuppressive steroidal glycosides from the stems of Stephanotis mucronata. Nat Prod Commun 7(10):1269-1270.

Liu Z, Zhong JY, Gao EN, et al (2014) Effects of glycyrrhizin and licorice flavonoids on LPSinduced cytokines expression in macrophages. China J Chinese Materia Medica 39(19):3841-3845.

Maione F, Russo R, Khan H, et al (2016) Medicinal plants with anti-inflammatory activities. Nat Prod Res 30(12):1343-1352.

Manglani PR, Arif MA (2006) Multidrug therapy in leprosy. J Indian Med Assoc 104(12):686688.

Matei D, Fang F, Shen C, et al (2012) Epigenetic resensitization to platinum in ovarian cancer. Cancer Res 72:2197-2205;

Mohamed AA, Ali SI, El-Baz FK, et al (2014) Chemical composition of essential oil and antimicrobial activities of crude extracts of Commiphora myrrha resin. Ind Crops Prod 57:10-16.

Mohan Maruga Raja KK, Mishra SH (2010) Comprehensive review of Clerodendrum phlomidis: a traditionally used bitter. J Chin Integr Med 8(6):510-524. 
Mokhtari RB, Homayouni TS, Baluch N, et al (2017) Combination therapy in combating cancer. Oncotarget: http://dx.doi.org/10.18632/oncotarget.16723.

Morris T, Stables M, Hobbs A, et al (2009) Effects of low-dose aspirin on acute inflammatory responses in humans. J Immunol 183(3):2089-2096.

Mutabingwa TK (2005) Atremisinin-based combination therapies (ACTs): Best hope for malaria treatment but inaccessible to the needy. Acta Tropica 95(3):305-315.

Nambi P, Aiyar N (2003) G protein-coupled receptors in drug discovery. Assay Drug Dev Technol 1(2):305-310.

Neubauer A (2017) Immunotherapy of cancer with checkpoint inhibitors: Not only in malignant melanoma. Der Internist 58(4):409-423.

Pan R, Dai Y, Gao X, et al (2009) Scopolin isolated from Erycibe obtusifolia Benth stems suppresses adjuvant-induced rat arthritis by inhibiting inflammation and angiogenesis. Int Immunopharmacol. 9:859-869.

Pareek A, Suthar M, Rathore GS, et al (2011) Feverfew (Tanacetum parthenium L.): A systematic review. Pharmacog Rev 5(9):103-110.

Penugonda K, Lindshield BL (2013) Fatty acid and phytosterol content of commercial saw palmetto supplements. Nutrients 5(9):3617-3633.

Pappová L, Jošová M, Kazimierová I, et al (2016) Combination therapy with Budesonide and Salmeterol in experimental allergy inflammation. In Pulmonary Infection and Inflammation: 25-34: Springer Publishing, NY USA.

Public Assessment Report. Scientific Discussion. (2014) TRINOMIA 100 mg/20 mg/2.5 mg hard capsules TRINOMIA 100 mg/20 mg/5 mg hard capsules TRINOMIA 100 mg/20 mg/10 mg hard capsules (Acetylsalicylic Acid, Atorvastatin calcium tryhidrate and Ramipril). Registration number in Spain: 74980. EU-procedure number: ES/H/0241/001003/DC, ES/H/0241/001/E/001-003

Quinn BA, Dash R, Sarkar S, et al (2015) Pancreatic cancer combination therapy using a BH3 mimetic and a synthetic tetracycline. Cancer Res 75:2305-2315.

Ramadan G, Al-Kahtani MA, El-Sayed WM (2014) Anti-inflammatory and antioxidant properties of Curcuma longa (Tumeric) versus Zingiber officinale (Ginger) rhizomes in rat adjuvant-induced arthritis. Inflammation 34(4):291-301. 
Richter M, Winkel AF, Schummer D, et al (2014) Pau d-arco activates Nrf2-dependent gene expression via the MEK/ERK-pathway. J Toxicol Sci 2:353-361.

Ruhaak LR, Felth J, Karlsson PC, et al (2011) Evaluation of the cyclooxygenase inhibiting effects of six major cannabinoids isolated from Cannabis sativa. Biol Pharm Bull 34:774778.

Saklani A, Hegde B, Mishra P, et al (2012) NF- $\kappa$ B dependent anti-inflammatory activity of chlorojanerin isolated from Saussurea heteromalla. Phytomedicine 19:988-997.

Schumacher M, Cerella C, Reuter S, et al (2011) Anti-inflammatory, pro-apoptotic, and antiproliferative effects of a methanolic neem (Azadirachta indica) leaf extract are mediated via modulation of the nuclear factor-кB pathway. Genes Nutr 6(2):149-160.

Spiller F, Alves MK, Vieira SM, et Al (2008) Anti-inflammatory effects of red pepper (Capsicum baccatum) on carrageenan- and antigen-induced inflammation. J Pharm Pharmacol 60(4):473-478.

Strauss J, Figg WD (2016) Using epigenetic therapy to overcome chemotherapy resistance. Anticancer Res 36(1):1-4.

Su S, Duan J, Chen T, et al (2015) Frankincense and myrrh suppress inflammation via regulation of the metabolic profiling and the MAPK signalling pathway. Sci Rep 5:13668

Sultan KS, Berkowitz JC, Khan S (2017) Combination therapy for inflammatory bowel disease. World J Gastrointest Pharmacol Ther 8(2):103-113.

Süntar I, Akkol EK, Baykal T (2010) Assessment of anti-inflammatory and antiociceptive activities of Olea europaea L. J Med Food 13(2):352-356.

Terra X, Montagut G, Bustos M, et al (2009) Grape-seed procyanidins prevent low-grade inflammation by modulating cytokine expression in rats fed a high-fat diet. J Nutr Biochem 20(3):210-218.

Tugwell P, Pincus T, Yocum D, et al (1995) Combination therapy with cyclosporine and methotrexate in severe rheumatoid arthritis. N Engl J Med 333(3):137-141.

Turner CE, Elshohly MA, Boeren EG (1980) Constituents of Cannabis sativa L. XVII. A review of the natural constituents. J Nat Prod 43(2):169-234. 
US Department of Health and Human Services, Food and Drug Administration. Guidance for Industry. Codevelopment of two or more new investigational drugs for use in combination.

http://www.fda.gov/Drugs/GuidanceComplianceRegulatoryInformation?Guidances?def ault.htm. 2013; Accessed 19 April 2018.

Van Voorhis WC, Adams JH, Adelfio R, et al (2016) Open source drug discovery with the malaria box compound collection for neglected diseases and beyond. PLoS Pathogens 12(7):e1005763

Van Wyk BE, van Oudtshoorn B, Gericke N (2009) Medicinal Plants of South Africa. Briza Publications, Pretoria Wsouth Africa; $2^{\text {nd }}$ edition:162-163.

Van Wyk B, Wink M (2004) Medicinal Plants of the World. Timber Press, Portland, Timber Press:329-430.

Watts CR, Rousseau B (2012) Slippery elm, its biochemistry, and use as a complementary and alternative treatment for laryngeal irritation. J Investig Biochem 1(1):17-23.

Weight SS, Purcell EM, Wilcox C, et al (1953) Antibiotic combinations and resistance to antibiotics. Development of resistance during repeated subcultures of Staphylococci and certain Streptococci on media containing penicillin, streptomycin, erythromycin, terramycin, and chloramphenicol used singly and in pairs. J Lab Clin Med 42(6):877895.

World Health Organisation (2018a) Leprosy.

http://www.who.int/mediacentre/factsheets/fs101/en/ cited 11 January 2018.

World Health Organisation (2018b) Overview of malaria treatment. http://www.who.int/mediacentre/factsheets/fs101/en/ cited 14 January 2018.

Worthington RJ, Melander C (2013) Overcoming resistance to $\beta$-lactam antibiotics. J Org Chem 78:4207-4213.

Xie YC, Dong XW, Wu XM, et al (2009) Inhibitory effect of flavonoids extracted from licorice on lipopolysaccharide-induced acute pulmonary inflammation in mice. International Immunopharmacol 9(2):194-200.

Xiong Y, Xiao B, Ma X, et al (2009) Effects of Gaultheria yunnanensis on adjuvant arthritis in rats. Chin. J. Chin. Mat. Med. 34:2516-2519. 
Yang MH, Ali Z, Khan IA, et al (2014) Anti-inflammatory activity of constituents isolated from Terminalia chebula. Nat Prod Commun 9(7):965-968.

Ye Y, Chen F, Sun H, et al (2008) Stemucronatoside K, a novel C21 steroidal glycoside from Stephanotis mucronata, inhibited the cellular and humoral immune response in mice. Int Immunopharmacol 8:1231-1238.

Zhang D, Liu R, Sun L, et al (2011) Anti-inflammatory activity of methyl salicylate glycosides isolated from Gaultheria yunnanensis (Franch.) Rehder. Molecules 16:3875-3884. 
Table 1: Some notable examples of diseases currently treated using combinational therapies and the advantages of these combinations over monotherapies.

\begin{tabular}{|c|c|c|c|c|c|}
\hline $\begin{array}{l}\text { Disease / } \\
\text { Pathogen }\end{array}$ & $\begin{array}{l}\text { Monotherapy } \\
\text { Option }\end{array}$ & Notes on Monotherapy & Drug Combination & $\begin{array}{l}\text { Reason for } \\
\text { Combination }\end{array}$ & References \\
\hline \multirow{3}{*}{$\begin{array}{l}\text { Bacterial } \\
\text { pathogens }\end{array}$} & \multirow{3}{*}{$\begin{array}{l}\text { Multiple } \\
\text { antibiotic options } \\
\text { options }\end{array}$} & $\begin{array}{l}\text { Many bacteria have } \\
\text { developed resistance to } \\
\beta \text {-lactam antibiotics via } \\
\text { the expression of } \beta \text { - } \\
\text { lactamase enzymes. }\end{array}$ & $\begin{array}{l}\beta \text {-lactam antibiotics (e.g. } \\
\text { amoxycillin) with } \beta \text { - } \\
\text { lactamase inhibitors (e.g. } \\
\text { clavulanic acid) }\end{array}$ & $\begin{array}{l}\text { Clavulanic acid binds } \\
\text { irreversibly to } \beta \text { - } \\
\text { lactamase, inactivating } \\
\text { the enzyme and thereby } \\
\text { increasing intracellular } \\
\text { antibiotic levels. }\end{array}$ & $\begin{array}{l}\text { Cheesman et } \\
\text { al 2017; } \\
\text { Worthington } \\
\text { and Melander } \\
2013\end{array}$ \\
\hline & & $\begin{array}{l}\text { Many gram negative } \\
\text { bacteria have developed } \\
\text { carbapenem resistance. }\end{array}$ & $\begin{array}{l}\text { Combinations of } \\
\text { carbapenems and imipenem } \\
\text { metallo } \beta \text {-lactamase } \\
\text { (IMBL) inhibitors }\end{array}$ & $\begin{array}{l}\text { IMBL inhibitors } \\
\text { inactivate IMBLs, } \\
\text { thereby increasing } \\
\text { intracellular antibiotic } \\
\text { levels. }\end{array}$ & $\begin{array}{l}\text { Cheesman et } \\
\text { al 2017; } \\
\text { Ahmed et al } \\
2014\end{array}$ \\
\hline & & $\begin{array}{l}\text { Antibiotic } \\
\text { monotherapies may be } \\
\text { ineffective due to } \\
\text { resistant bacterial } \\
\text { strains. The use of }>1 \\
\text { antibiotic increases the } \\
\text { chance of an effective } \\
\text { therapy. Furthermore, } \\
\text { some bacterial } \\
\text { infections may be } \\
\text { polymicrobial. }\end{array}$ & $\begin{array}{l}\text { Combinations of antibiotic } \\
\text { drugs that act via different } \\
\text { mechanisms }\end{array}$ & $\begin{array}{l}\text { Combining antibiotics } \\
\text { which act by different } \\
\text { mechanisms may } \\
\text { increase their } \\
\text { bacteriocidal or } \\
\text { bacteriostatic efficacy. }\end{array}$ & $\begin{array}{l}\text { Cheesman et } \\
\text { al 2017; } \\
\text { Worthington } \\
\text { and Melander } \\
2013\end{array}$ \\
\hline
\end{tabular}


Bacterial efflux pumps reduce intracellular antibiotic

concentrations, thereby decreasing the drug's efficacy. The use of of antibiotic efflux pump inhibitors often overcomes this and efflux pump inhibitors (EPIs).

Blocking bacterial efflux of antibiotics increases their intracellular levels, increasing antibiotic efficacy.

Cheesman et al 2017; Worthington and Melander 2013 resistance.

Monotherapy for leprosy is considered unethical as it will always result in Mycobacterium leprae developing resistance to that drug.

Leprosy is always treated using multidrug therapies (commonly including rifampicin, clofazimine and dapsone)
Combinations provide

multiple antibiotic

mechanisms, thereby decreasing the chance

of the bacterium

developing resistance to

WHO 2018;

Manglani and any of the antibiotic components.

\section{ACTs have}

substantially greater

efficacy than

Artemisinin-based

have developed

Artemisinin and

Plasmodium its derivatives are falciperum the current gold standard drugs resistance to artemisinin and its derivatives and combinations are now recommended. WHO describes monotherapies of artemisinin and it derivatives as unethical.

\section{(ACTs) combining fast}

acting artemisinin

derivative drugs with an

antimalarial drug from a

different class (e.g.

lumefantrine, mefloquine, sulfadoxine/pyrimethamine, piperquine,

chlorproguanil/dapsone). monotherapies, are

faster acting and reduce WHO 2018; the likelihood of the Ginsburg and parasite developing Deharo 2011; resistance. Different Mutabingwa components in the 2005 combination target different pathways or stages of the pathogen's life cycle. 
Multiple anti-

retroviral options,

most frequently

targeting HIV

reverse

transcriptase

(HIV-RT). Drugs

targeting viral

binding to cell

receptors, cell

entry, HIV

integrase and

HIV protease are

also used.
AZT monotherapy was initially effective.

However, the virus has

developed AZT

resistance and the use of drug combinations are now common.
Typically, combinations consist of at least 2 nucleoside reverse transcriptase inhibitors, combined with 1 non-

nucleoside reverse transcriptase inhibitor, or protease or integrase inhibitors.

The combination of

nucleoside reverse

transcriptase inhibitors increases the likelihood

that the therapy will

block viral replication.

Addition of HIV

Adams et al

protease or integrase

2004

inhibitors provide

multiple antiviral

mechanisms, thereby

increasing the efficacy

of the therapy.

Combining drugs that

act by different

mechanisms may

Cancer chemotherapies

toxic. Prolonged use

Cancer

chemotherapeutic

may result in

options

insensitivities and

resistances in some

Combinations of drugs that act via different

increase their

cytotoxicity efficacy

towards tumour cells,

Mokhtari et al

mechanisms

reduce the likelihood of

developing resistance

and minimise

overlapping toxicity. 
Some cancer cells over express ATP-binding cassette (ABC)

transporters that pump chemotherapeutics out of the cell, lessening their effects.

\section{Prolonged}

chemotherapy treatment may induce epigenetic

alterations (e.g.

methylation), resulting

in resistance to the drug.

\section{Combinations allow}

A combination of cytotoxic compound(s) and $\mathrm{ABC}$ transport inhibitors higher concentrations of Mokhtari et al cytotoxic compounds to 2017; Khadir accumulate inside the et al 2010 cell.

\section{An example is cisplatin in}

combination with

decitabine which reverses

DNA methylation and resensitises hMLH1

ovarian cancer cells to cisplatin.

Cancer cells may develop resistance to checkpoint inhibitors, rendering them ineffective as cytostatic therapies.

\section{A combination of}

checkpoint inhibitors and drugs that prevent cancer cells from inactivating $\mathrm{T}$ cells.
Immunotherapies in combination with checkpoint inhibitors may counteract the development of Neubauer resistance and has been 2017 shown to be effective in checkpoint resistant melanomas and breast cancer tumours.

\section{Co-administration of cancer therapeutics with drugs that reverse the epigenetic alteration. \\ Mokhtari et al 2017; Strauss and Figg 2016; Matei et al 2012}


Carbonic anhydrase

(CA) is upregulated in some cancers to adapt to hypoxic stress by regulating cellular $\mathrm{pH}$.

Thus, therapies

targeting CA may

inhibit cancer growth and progression.

A combination of carbonic and other anticancer drugs such as sulforaphane (SFN)

Efficacy may be enhanced by targeting antioxidant responsive pathways.

A combination of cancer

drug(s) in combination with drugs with high antioxidant capacity. anhydrase inhibitors (CAI)

SFN downregulates the expression of Bcl-2

(anti-apoptotic gene),

thus inducing apoptosis.

The effect is potentiated

in combination with

CAI against some cells

(e.g. MCF-7 human breast cancer cells).

\section{High antioxidant}

compounds (e.g. curcumin) often induce

upregulation of Nrf2

and its translocation to

Mokhtari et al

the nucleus, thus

inducing apoptosis. 
Table 2: Some notable plants used in traditional healing systems to treat and alleviate the symptoms of inflammation.

\begin{tabular}{|c|c|c|c|c|c|}
\hline Plant species & Common name & Comments & $\begin{array}{c}\text { Active Compound(s) (if } \\
\text { known) }\end{array}$ & Mechanism of Action & References \\
\hline $\begin{array}{l}\text { Allium sativum } \\
\text { L. }\end{array}$ & Garlic & $\begin{array}{l}\text { A. sativum (and } \\
\text { other related Allium } \\
\text { spp.) are reputed to } \\
\text { have anti- } \\
\text { inflammatory, } \\
\text { anticancer and } \\
\text { antiviral activities. }\end{array}$ & $\begin{array}{l}\text { High in sulfur containing } \\
\text { compounds including } \\
\text { alliin, ajoene, S-allyl } \\
\text { cysteine etc. Also } \\
\text { contains saponins and } \\
\text { flavonoids in significant } \\
\text { levels. }\end{array}$ & $\begin{array}{l}\text { Suppresses } \\
\text { inflammatory cytokine } \\
\text { production }\end{array}$ & $\begin{array}{l}\text { Caspasso } \\
\text { 2013; Hodge } \\
\text { et al } 2002\end{array}$ \\
\hline $\begin{array}{l}\text { Aloe vera (L.) } \\
\text { Burm.f }\end{array}$ & $\begin{array}{l}\text { Aloe vera, burns } \\
\text { plant, Barbados } \\
\text { aloe, common aloe }\end{array}$ & $\begin{array}{l}\text { Multiple other Aloe } \\
\text { species including } A \text {. } \\
\text { ferox, } A \text {. } \\
\text { arborescens, etc. } \\
\text { have similar } \\
\text { therapetuic } \\
\text { properties including } \\
\text { anti-inflammatory, } \\
\text { anticancer, } \\
\text { antibacterial } \\
\text { activities }\end{array}$ & $\begin{array}{l}\text { Anthraquinones, } \\
\text { anthrones, flavonoids, } \\
\text { phytosterols }\end{array}$ & $\begin{array}{l}\text { Acemannan activates } \\
\text { macrophages and } \\
\text { stimulates the secretion } \\
\text { of IL-1, IL-6, inteferon, } \\
\text { GM-CSF and TNF- } \alpha \text {. } \\
\text { The anthraquinones } \\
\text { reduce TNF- } \alpha \text {, IL-1, IL- } \\
2 \text { and IL-2 receptor } \\
\text { expression, whilst } \\
\text { increasing IL-10 } \\
\text { expression. B-sitosterol } \\
\text { blocks prostacyclin and } \\
\text { prostaglandin release. } \\
\text { Aloesin inhibits COX-2 }\end{array}$ & Cock 2015a \\
\hline
\end{tabular}


Used in Ayurveda

and Siddha to treat

inflammation and

Azadirachta
indica A.Juss. Neem

skin diseases

including eczema,

\section{Liminoids}

Inhibition of NF-kB

psoriasis etc. Also

used as an

antimicrobial.

Multiple species are

known including $B$.

carterii, $B$, sacra, $B$.

serratia. All are

known for a wide

Boswellia spp. Frankincense

array of therapetuic

properties including

anti-inflammatory,

anticancer and

antibacterial

activities

The related species

$C$. indica and $C$.

ruderalis have

Cannabis sativa Cannabis, marijuana similar

phytochemistry and

therapeutic

properties.

There are multiple

species and

cultivars which vary

widely in their

Capsicum spp. Chilli pepper

intensity of taste capsaicinoids and

tetrahydrocannabinol,

Inhibits COX-2

cannabidiol, cannabinol

carotenoids.
Cannabanoids including
Triterpenoids (including

,

monoterpenoids

Inhibition of pro-

inflammatory cytokines

TNF- $\alpha$ and IL- $1 \beta$. Also

has analgesic effects
Akihisa et al

2011;

Schumacher

et al 2010;

Biswas et al

2002

Biggs et al

2016a; Su et

al 2015; Li et

al 2015;

Gayathri et al

2007; Banno

et al 2006 
and levels of active

compounds.

\begin{tabular}{|c|c|c|c|c|c|}
\hline $\begin{array}{l}\text { Clerodendrum } \\
\text { phlomidis L.f. }\end{array}$ & Arni, Arna Urni & $\begin{array}{l}\text { Used in Ayuverda } \\
\text { to treat } \\
\text { inflammation and } \\
\text { swelling. }\end{array}$ & $\begin{array}{l}\beta \text {-sitosterol, } \curlyvee \text {-sitosterol, } \\
\text { flavonoids including } \\
\text { pectolinaringenin and } \\
\text { scutellarein }\end{array}$ & $\begin{array}{l}\text { Decreases pro- } \\
\text { inflammatory cytokines. }\end{array}$ & $\begin{array}{l}\text { Babu et al } \\
\text { 2011; Mohan } \\
\text { Maruga Raja } \\
\text { and Mishra } \\
2010\end{array}$ \\
\hline $\begin{array}{l}\text { Commiphora } \\
\text { molmol (Nees) } \\
\text { Engl. }\end{array}$ & Myrhh & $\begin{array}{l}\text { Has a wide array of } \\
\text { therapeutic } \\
\text { properties including } \\
\text { anti-inflammatory, } \\
\text { anticancer and } \\
\text { antibacterial } \\
\text { activities }\end{array}$ & $\begin{array}{l}\text { m-Cresol, eugenol, } \\
\text { sesquiteriterpenoids, } \\
\text { lindestrene, } \\
\text { furaneudesma-1,3-diene }\end{array}$ & $\begin{array}{l}\text { Has analgesic effects for } \\
\text { fibromyalgia and } \\
\text { rheumatism. }\end{array}$ & $\begin{array}{l}\text { Biggs et al } \\
\text { 2016b; } \\
\text { Mohamed et } \\
\text { al } 2014\end{array}$ \\
\hline $\begin{array}{l}\text { Curcuma longa } \\
\text { L. }\end{array}$ & Tumeric & $\begin{array}{l}\text { Used in Ayuverda } \\
\text { to treat } \\
\text { inflammation, } \\
\text { cancer, } \\
\text { cardiovascular and } \\
\text { gastrointestinal } \\
\text { disease. Also has } \\
\text { antimicrobial } \\
\text { properties. }\end{array}$ & Curcumin & $\begin{array}{l}\text { Inhibits } \\
\text { cyclooxygenase, 5- } \\
\text { lipoxygenase and } \\
\text { glutathione-S- } \\
\text { transferase. It also } \\
\text { lowers histamine } \\
\text { release. }\end{array}$ & $\begin{array}{l}\text { Ramadan et } \\
\text { al 2011; } \\
\text { Akram et al } \\
2010\end{array}$ \\
\hline
\end{tabular}


Used in TCM to

treat rheumatoid

arthritis and other

\begin{tabular}{|c|c|c|c|c|c|}
\hline $\begin{array}{l}\text { Erycibe } \\
\text { obtusifolia } \\
\text { Benth. }\end{array}$ & Dinggongteng & $\begin{array}{l}\text { inflammation. } \\
\text { Usually used in } \\
\text { combination with } \\
>20 \text { other herbs in a } \\
\text { preparation called } \\
\text { Dinggongteng } \\
\text { Fengshi Yaojiu. }\end{array}$ & Scopolin & $\begin{array}{l}\text { symptoms of } \\
\text { inflammation by } \\
\text { modulating cytokine } \\
\text { levels. It also stimulates } \\
\text { angiogenesis. }\end{array}$ & $\begin{array}{l}\text { Pan et al } \\
2009\end{array}$ \\
\hline $\begin{array}{l}\text { Garcinia } \\
\text { mangostana L. }\end{array}$ & Purple mangosteen & $\begin{array}{l}\text { Used in multiple } \\
\text { Southeast Asian } \\
\text { traditional medicine } \\
\text { systems for the } \\
\text { treatment of } \\
\text { inflammation, } \\
\text { bacterial infections, } \\
\text { gastrointestinal } \\
\text { complaints and } \\
\text { urinary tract } \\
\text { infections. }\end{array}$ & Isogarcinol & $\begin{array}{l}\text { Modulation of iNOS } \\
\text { and COX-2 expression. }\end{array}$ & $\begin{array}{l}\text { Maione et al } \\
\text { 2016; Fu et al } \\
2014\end{array}$ \\
\hline $\begin{array}{l}\text { Gaultheria } \\
\text { yunnanensis } \\
\text { (Franch.) }\end{array}$ & Wintergreen & $\begin{array}{l}\text { Used in TCM to } \\
\text { treat rheumatoid } \\
\text { arthritis }\end{array}$ & $\begin{array}{l}\text { Methyl salicylate } \\
\text { glycosides }\end{array}$ & $\begin{array}{l}\text { Suppresses the pro- } \\
\text { inflammatory cytokines } \\
\text { TNF- } \alpha, \text { IL-1 } \beta \text { and IL- } 6 \text {. }\end{array}$ & $\begin{array}{l}\text { Zhang et al } \\
\text { 2011; Xiong } \\
\text { et al } 2009\end{array}$ \\
\hline
\end{tabular}

Scopolin reduces the symptoms of inflammation by

Pan et al levels. It also stimulates angiogenesis.

Used in multiple

systems for the

treatment of

bacterial infections, and COX-2 expression.
2016; Fu et al

gastrointestinal

complaints and

infections. yunnanensis

(Franch.) arthritis
2011; Xiong 


\begin{tabular}{|c|c|c|c|c|c|}
\hline $\begin{array}{l}\text { Glycyrrhiza } \\
\text { glabra L. }\end{array}$ & Licorice, liquorice & $\begin{array}{l}\text { Used in multiple } \\
\text { Asian, northern } \\
\text { African and } \\
\text { European traditional } \\
\text { healing systems to } \\
\text { treat inflammation, } \\
\text { chronic gastritis, } \\
\text { jaundice, and } \\
\text { rheumatism. Also } \\
\text { has anti-infective } \\
\text { properties. }\end{array}$ & $\begin{array}{l}\text { Glycyrrhizin, glabbrene, } \\
\text { glabridin, anthole and } \\
\text { several phytoestrogens. }\end{array}$ & $\begin{array}{l}\text { Suppresses pro- } \\
\text { inflammatory cytokines. }\end{array}$ & $\begin{array}{l}\text { Liu et al } \\
\text { 2014; Xie et } \\
\text { al } 2009\end{array}$ \\
\hline $\begin{array}{l}\text { Harpagophytum } \\
\text { procumbens } \\
\text { (Burch.) DC. ex } \\
\text { Meisn. }\end{array}$ & Devil's claw & $\begin{array}{l}\text { Used in multiple } \\
\text { traditional African } \\
\text { medicine systems to } \\
\text { treat inflammation. } \\
\text { Also has } \\
\text { antimicrobial } \\
\text { properties. }\end{array}$ & $\begin{array}{l}\text { Verbascoside, } \\
\text { leveosceptoside A, } \beta \text { - } \\
\text { OH-verbascoside, } \\
\text { martynoside }\end{array}$ & $\begin{array}{l}\text { Suppresses pro- } \\
\text { inflammatory cytokines } \\
\text { and inhibits } \\
\text { cyclooxygenase } \\
\text { expression. }\end{array}$ & $\begin{array}{l}\text { Gyurkovska } \\
\text { et al 2011; } \\
\text { van Wyk et } \\
\text { al 2009; Jang } \\
\text { et al 2003 }\end{array}$ \\
\hline $\begin{array}{l}\text { Juglans regia } \\
\text { L. }\end{array}$ & English walnut & $\begin{array}{l}\text { Several related } \\
\text { species (J. nigra, } J \text {. } \\
\text { cinerea) have } \\
\text { similar traditional } \\
\text { uses for } \\
\text { inflammation, } \\
\text { cancer, } \\
\text { immunomodulation } \\
\text { and diabetes } \\
\text { mellitus. }\end{array}$ & $\begin{array}{l}\text { High levels of omega-3 } \\
\text { fatty acids }\end{array}$ & $\begin{array}{l}\text { Increases the expression } \\
\text { of the cytokine } \\
\text { associated protein } \\
\text { MAIL. The high levels } \\
\text { of unsaturated fatty } \\
\text { acids protect against } \\
\text { oxidative stress. }\end{array}$ & $\begin{array}{l}\text { Lebaratoux et } \\
\text { al 2016; } \\
\text { Carey et al } \\
2013\end{array}$ \\
\hline
\end{tabular}




\begin{tabular}{|c|c|c|c|c|c|}
\hline $\begin{array}{l}\text { Magnolia } \\
\text { officinalis } \\
\text { Rehder \& } \\
\text { Wilson }\end{array}$ & $\begin{array}{l}\text { Houpu magnolia, } \\
\text { hou po (in TCM) }\end{array}$ & $\begin{array}{l}\text { Alleviates } \\
\text { inflammation and } \\
\text { protects against } \\
\text { cancer. }\end{array}$ & $\begin{array}{l}\text { Honokiol, } \\
\text { sesquiterpenoids }\end{array}$ & $\begin{array}{l}\text { Alleviates the symptoms } \\
\text { of inflammatory } \\
\text { arthritis. }\end{array}$ & $\begin{array}{l}\text { Feltenstein et } \\
\text { al } 2004\end{array}$ \\
\hline $\begin{array}{l}\text { Olea europaea } \\
\text { L. }\end{array}$ & Olive & $\begin{array}{l}\text { Has anti- } \\
\text { inflammatory } \\
\text { properties and } \\
\text { lowers blood } \\
\text { glucose and } \\
\text { cholesterol. Also } \\
\text { has antimicrobial } \\
\text { activity. May lose } \\
\text { therapeutic benefits } \\
\text { if heated. }\end{array}$ & $\begin{array}{l}\text { Oleocanthal. Also } \\
\text { contains flavonoids and } \\
\text { terpenoids }\end{array}$ & $\begin{array}{l}\text { Inhibits the expression } \\
\text { of pro-inflammatory } \\
\text { enzymes }\end{array}$ & $\begin{array}{l}\text { Süntar et al } \\
2010 \text {; El et al } \\
2009\end{array}$ \\
\hline $\begin{array}{l}\text { Saussurea } \\
\text { heteromalla (D. } \\
\text { Don) Hand. } \\
\text { Mazz. }\end{array}$ & $\begin{array}{l}\text { Kaliziri, Murang, } \\
\text { Batula }\end{array}$ & $\begin{array}{l}\text { Used in Ayuverda } \\
\text { to treat } \\
\text { inflammation, colic, } \\
\text { fever and for wound } \\
\text { healing. }\end{array}$ & Chlorojanerin & $\begin{array}{l}\text { Inhibits TNF- } \alpha \text { and IL-6 } \\
\text { production. Also } \\
\text { inhibits monocyte } \\
\text { function. }\end{array}$ & $\begin{array}{l}\text { Saklani et al } \\
2012\end{array}$ \\
\hline $\begin{array}{l}\text { Serenoa repens } \\
\text { Hook.f. }\end{array}$ & Saw palmetto. & $\begin{array}{l}\text { Best known for the } \\
\text { treatment of benign } \\
\text { prostatic } \\
\text { hyperplasia and } \\
\text { prostate cancer, as } \\
\text { well as urinary tract } \\
\text { problems. Was also } \\
\text { used by the } \\
\text { Seminoles as an } \\
\text { antiseptic. Caution } \\
\text { is advised with its } \\
\text { use due to multiple }\end{array}$ & $\begin{array}{l}\text { Substantial levels of } \\
\text { phytosterols (campesterol, } \\
\text { stigmasterol, } \beta \text {-sitosterol) } \\
\text { and high levels of fatty } \\
\text { acids. }\end{array}$ & $\begin{array}{l}\text { Inhibits 5-lipoxygenase } \\
\text { and cyclooxygenase }\end{array}$ & $\begin{array}{l}\text { Cock 2015b; } \\
\text { Penugonda } \\
\text { and } \\
\text { Lindshield } \\
2013\end{array}$ \\
\hline
\end{tabular}


interactions with

other drugs.

\begin{tabular}{|c|c|c|c|c|c|}
\hline $\begin{array}{l}\text { Stephanotis } \\
\text { mucronata } \\
\text { Merr. }\end{array}$ & $\begin{array}{l}\text { Shitaki-sou } \\
\text { (Japanese) }\end{array}$ & $\begin{array}{l}\text { Used in TCM for } \\
\text { the treatment of } \\
\text { rheumatoid arthritis. }\end{array}$ & $\begin{array}{l}\text { Steroidal glycosides and } \\
\text { saponins }\end{array}$ & Immunomodulation. & $\begin{array}{l}\text { Li et al 2012; } \\
\text { Ye et al 2008 }\end{array}$ \\
\hline $\begin{array}{l}\text { Tanacetum } \\
\text { parthenium (L.) } \\
\text { Sch.Bip. }\end{array}$ & Feverfew & $\begin{array}{l}\text { Used to treat } \\
\text { arthritis and } \\
\text { inflammation and to } \\
\text { reduce fever. }\end{array}$ & Parthenolide & $\begin{array}{l}\text { Modulation of NF-кB, } \\
\text { interferes with } \\
\text { microtubule formation. } \\
\text { Has both anti- } \\
\text { inflammatory and } \\
\text { analgesic effects. Also } \\
\text { induces apoptosis in } \\
\text { some cancer cells. }\end{array}$ & $\begin{array}{l}\text { Pareek et al } \\
2011\end{array}$ \\
\hline $\begin{array}{l}\text { Tabebuia } \\
\text { impetiginosa } \\
\text { (Mart. Ex DC.) } \\
\text { Mattos }\end{array}$ & $\begin{array}{l}\text { Pau d'arco } \\
\text { (Portuguese), } \\
\text { lapacho (Spanish), } \\
\text { pink ipe, pink } \\
\text { lapacho, pink } \\
\text { trumpet tree }\end{array}$ & $\begin{array}{l}\text { Used in Central and } \\
\text { South American } \\
\text { traditional medicine } \\
\text { systems to treat } \\
\text { inflammation, } \\
\text { cancer, stomach } \\
\text { disorders and } \\
\text { microbial } \\
\text { infections. }\end{array}$ & $\begin{array}{l}\text { Lapachol and } \beta \text { - } \\
\text { lapachone. }\end{array}$ & $\begin{array}{l}\text { Suppresses the } \\
\text { production of } \\
\text { prostaglandin E2 and } \\
\text { NO. It also blocks the } \\
\text { expression of COX-2 } \\
\text { and iNOS and activates } \\
\text { Nrf2-dependent gene } \\
\text { expression. }\end{array}$ & $\begin{array}{l}\text { Richter et al } \\
2014 \text {; Byeon } \\
\text { et al } 2008\end{array}$ \\
\hline
\end{tabular}




\begin{tabular}{|c|c|c|c|c|c|}
\hline $\begin{array}{l}\text { Terminalia } \\
\text { chebula Retz. }\end{array}$ & $\begin{array}{l}\text { black myrobalan, } \\
\text { chebulic myroblan, } \\
\text { inknut }\end{array}$ & $\begin{array}{l}\text { Used to treat } \\
\text { inflammation and } \\
\text { tumours. Also used } \\
\text { for the treatment of } \\
\text { coughs and colds, } \\
\text { digestive disorders, } \\
\text { and as an } \\
\text { antimicrobial } \\
\text { treatment. Multiple } \\
\text { other Terminalia } \\
\text { spp. have similar } \\
\text { therapeutic uses. }\end{array}$ & $\begin{array}{l}\text { Rich in galloyl- and } \\
\text { ellagi-tannins (including } \\
\text { chebulis acid). Also } \\
\text { contains substantial } \\
\text { triterpenoid levels. }\end{array}$ & $\begin{array}{l}\text { Inhibits iNOS and } \\
\text { COX-2 }\end{array}$ & $\begin{array}{l}\text { Cock 2015c; } \\
\text { Yang et al } \\
\text { 2014; Kim et } \\
\text { al 2010 }\end{array}$ \\
\hline $\begin{array}{l}\text { Ulmus rubra } \\
\text { Muhl. }\end{array}$ & Slippery elm & $\begin{array}{l}\text { Used to relieve pain } \\
\text { and inflammation. } \\
\text { Often used in } \\
\text { combination with } \\
\text { Burdock root, sheep } \\
\text { sorrel and Indian } \\
\text { rhubarb root in a } \\
\text { formulation known } \\
\text { as essiac. }\end{array}$ & $\begin{array}{l}\text { High levels of the } \\
\text { polysaccharide mucilage. } \\
\text { Also contains substantial } \\
\text { levels of tannins, } \beta \text { - } \\
\text { sitosterol and flavonoids. }\end{array}$ & $\begin{array}{l}\text { Strong antioxidant } \\
\text { activity. Scavenges free } \\
\text { radicals. }\end{array}$ & $\begin{array}{l}\text { Watts and } \\
\text { Rosseau } \\
\text { 2012; van } \\
\text { Wyk and } \\
\text { Wink } 2008\end{array}$ \\
\hline Vitis vinifera $\mathrm{L}$. & Grape & $\begin{array}{l}\text { Seed extracts and } \\
\text { fruit skins have } \\
\text { anti-inflammatory } \\
\text { properties }\end{array}$ & $\begin{array}{l}\text { Resveratrol (and other } \\
\text { stilbenoids), } \\
\text { anthocyanins, } \\
\text { hydroxycinnamic acids, } \\
\text { tannins }\end{array}$ & $\begin{array}{l}\text { Suppresses the pro- } \\
\text { inflammatory cytokines } \\
\text { TNF- } \alpha \text { and IL- } 6 \text {. }\end{array}$ & $\begin{array}{l}\text { Terra et al } \\
2009\end{array}$ \\
\hline
\end{tabular}


Used in Ayurveda

to treat

\begin{tabular}{|c|c|c|c|c|c|}
\hline $\begin{array}{l}\text { Withania } \\
\text { somnifera (L.) } \\
\text { Dunal }\end{array}$ & $\begin{array}{l}\text { Ashwagandha } \\
\text { (Indian), Indian } \\
\text { ginseng, poison } \\
\text { gooseberry, winter } \\
\text { cherry. }\end{array}$ & $\begin{array}{l}\text { inflammation and } \\
\text { rheumatism, } \\
\text { microbial diseases, } \\
\text { gastrointestinal } \\
\text { disease and a wide } \\
\text { variety of other } \\
\text { illness. }\end{array}$ & $\begin{array}{l}\text { Alkaloids and steroidal } \\
\text { lactones, including } \\
\text { withaferin A }\end{array}$ & $\begin{array}{l}\text { Modulates COX-2 } \\
\text { expression. }\end{array}$ & $\begin{array}{l}\text { Kim and Kim } \\
2014 .\end{array}$ \\
\hline $\begin{array}{l}\text { Zingiber } \\
\text { officinale } \\
\text { Roscoe }\end{array}$ & Ginger & $\begin{array}{l}\text { Has anti- } \\
\text { inflammatory and } \\
\text { antimicrobial } \\
\text { properties. }\end{array}$ & Gingerol, flavonoids & $\begin{array}{l}\text { Immunomodulation. } \\
\text { Inhibits PGE } \\
\text { production and } \\
\text { decreases the levels of } \\
\text { pro-inflammatory } \\
\text { cytokines. }\end{array}$ & $\begin{array}{l}\text { Ramadan et } \\
\text { al 2011; Adel } \\
\text { and Prakash } \\
\text { 2010; } \\
\text { Grzanna et al } \\
2005\end{array}$ \\
\hline
\end{tabular}

